\title{
THE GENEALOGY OF THE VIRGIN MARY IN SINAI SYR. 16
}

No one has done more than Michel van Esbroeck in drawing attention, through his numerous publications of new texts, to the riches of patristic literature that lie hidden in manuscripts written in the languages of the Christian Orient. Among these publications it is not difficult to discern a particular interest in texts the popular traditions that grew up surrounding the Virgin Mary. It is thus a great pleasure to have the opportunity to offer, by way of a small tribute to his great scholarship and learning, a Syriac counterpart, as it were, to his «Généalogie de la Vierge en géorgien». ${ }^{1}$

The interest of some of the texts in Sinai Syr. 16 became apparent even before the appearance of Mrs A. S. Lewis' Catalogue in 1894 thanks to J. Rendel Harris' publication (in 1891), from this manuscript, of the Syriac text of the Apology of Aristides (CPG 1062), and the discovery (by J. A. Robinson) that the underlying Greek text was in fact preserved almost complete, incorporated into the Life of Barlaam and Ioasaph (CPG 8120). Since both Harris and Lewis only provided summary indications of the rest of the contents of Sinai Syri. 16, a much fuller description of its contents is given in Appendix 2, below. ${ }^{2}$ Among the items in the manuscript of which Harris and Lewis make no mention is the following, on f. 200r. 1:

Next, an account concerning the ancestors of the Bearer of God, composed by the Fathers of the circle (d-beth) of Gregory. ${ }^{3}$

The short ensuing text (f. 200r. 1-2) reads as follows:

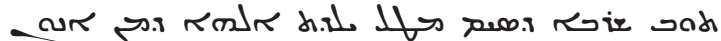

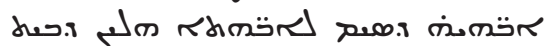

$$
\begin{aligned}
& \text { onit } \\
& \text { אلעוl }
\end{aligned}
$$

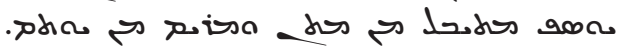

\footnotetext{
${ }^{1} A B 91$ (1973) 347-356.
}

${ }^{2}$ I take the opportunity to thank His Grace Archbishop Damianos, the Librarian and the Synaxis of the Holy Monastery of St Catherine, Sinai, for the opportunity to look at this manuscript during my visit to the Monastery to catalogue the Syriac fragments from the New Finds.

${ }^{3}$ It is unclear which Gregory is intended; possibly the attribution was suggested by Gregory of Nyssa, On the Nativity ( $P G 46.1137 \mathrm{D})$, where a narrative concerning Mary's parents is mentioned, but without any names being mentioned. 


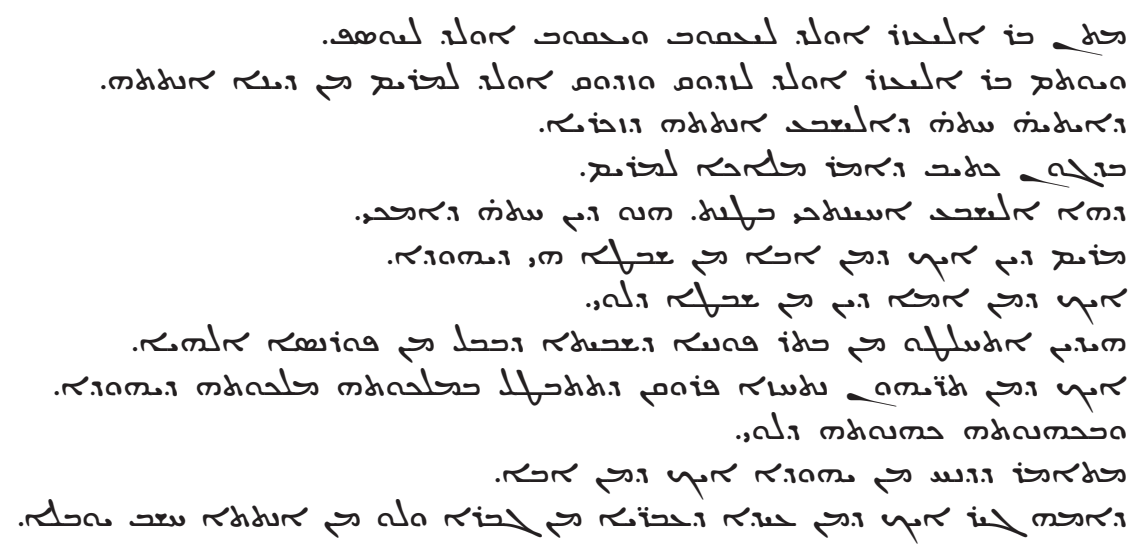

Eleazar (Mt 1:15) had two children, the one Mathan (Mt 1:15), and the other Jotham. Joseph is descended from Mathan and Mary from Jotham. Eleazar's son Mathan begot Jacob, and Jacob begot Joseph. And Eleazar's son Jotham begot Zadoq, and Zadoq begot Mary by his wife Dina, who is the sister of Elisabeth, the wife of Zechariah. For this reason it is written that the Angel said to Mary, «Behold, Elisabeth your relative has conceived» (Lk 1:36) — that is, the sister of your mother. Now Mary from her father's side was from the tribe of Judah, but from her mother's side, from the tribe of Levi. Then the (tribes) were intermingled after the return from the Babylonian captivity through divine providence, so that our Saviour might be seen as being from both of them, in order that, through his kingship, the kingship of Judah might become ineffective, and through his priesthood, the (same would apply to the) priesthood of Levi. It is (thus) said that «he arose from Judah» (Heb 7:14), on his father's side, for his mother's genealogy, according to the custom of the Hebrews, reckons from the husband, and not from the wife.

Mary, of course, does not feature at all in the genealogies given in Matthew 1 and Luke 3. Earlier commentators were more interested in providing explanations for the apparent contradictions between the two lists (exemplified by Joseph's father being Jacob in Matthew and Eli in Luke). Here, one of the most influential texts was the Letter of Africanus to Aristides (CPG 1693), who neatly solved the problem by reference to levirate marriage (Deut 25:5) and the concept of a legal, alongside that of a natural, son. As will be seen below, this explanation was current in Syriac circles ${ }^{4}$ in an adapted form, attributed to Theodore of Mopsuestia.

${ }^{4}$ Probably by way of the Syriac translation of Eusebius' Gospel Questions and Answers, for which see G. BEYER, Die evangelischen Fragen und Lösungen des Eusebius in jakobitischer Überlieferung und deren nestorianischen Parallelen // Oriens Christianus ns 12/14 (1925) 50-69. 
A second concern was to provide a Davidic ancestry for Mary, as well as that given in the Gospels for Joseph. This was done by showing how Mary and Joseph were related (see Appendix 1).

Yet another concern, which might or might not involve the genealogies, was the matter of Christ's priesthood. In the New Testament this was seen as being «of the order of Melkizedek» (Hebrews 5:6), that is, non-levitical. Earlier Syriac tradition, represented by Aphrahat and Ephrem (and also found in the Teaching of Gregory the Illuminator, section 433), also had an interest in his levitical priesthood, and saw this as having been transferred to him by John the Baptist at the Baptism. ${ }^{5}$ Evidently at an early date in Syriac tradition some people wanted to see Christ's levitical priesthood transmitted directly through the genealogy of Mary, and this is explicitly stated in the Armenian translation of the Commentary on the Diatessaron (I.25), attributed to Ephrem, in contrast to the Syriac text (I.25-26) which goes out of its way to argue that Mary was not of levitical descent, and the Gospel statement that Elisabeth was her «relative» (Luke 2:36) was not to be taken in a literal sense. ${ }^{6}$

The same concern with Christ's levitical priesthood is also found in our present text which, in line with the Armenian translation of the Commentary on the Diatessaron, takes this back to his very birth, through the actual construction of a genealogy for Mary.

Speculation concerning the parents of Mary first surface in the Protogospel of James, which set the mainstream tradition of naming them as Joachim and Anna. The same work also states that Mary was from «the tribe(!) of David», and it was probably a concern to show Christ's Davidic descent through Mary, as opposed to Joseph, that speculation about her ancestry developed. A full-blown genealogy for Mary, traced back through Joachim and Anna, was subsequently provided in the Life of the Virgin by Epiphanius the monk ( $9^{\text {th }}$ century; BHG 1049), whereby she is also related to Joseph and Elisabeth. A related genealogy for Mary is known to Jacob of Edessa (d. 708) who, in one of his Letters, says that «There are some narratives written by certain zealous people on their own authority, without having any testimonies from Scripture, which show that Mary, the holy Virgin, the mother of

${ }^{5}$ Aphrahat, Dem. VI.13, XXI.13, XXIII.20; Ephrem, Hymni c. Haereses XXII.19; Comm. Diatessaron IV.3; elsewhere (Sermo de Domino Nostro LIII) Ephrem associates the transfer as having come through Simeon at the Presentation in the Temple. See further R. Murray, Symbols of Church and Kingdom. A Study in Early Syriac Tradition (Cambridge, 1975'; 2004²) 178-182.

${ }^{6}$ See D. G. K. TAYlor, The priesthood of Christ in early Syriac tradition // SP, forthcoming (I am most grateful to David Taylor for letting me see his paper). For the differences between the Syriac and the Armenian, see C. LANGe, The descent of Mary and the Syriac Commentary on the Diatessaron // The Harp (Kottayam) 15 (2002) $107-116$. 
Christ, was the daughter of Hanna and of the upright Ioakin, concerning whom those who authored the narratives say that he was the son of Panther, and Panther was the brother of Melki, the son of Yani (Lk 3:24) who descends from the lineage of Levi in the genealogy. He was living in the region of Galilee, in the vicinity of the place where the town of Tiberias was built». ${ }^{7}$ Jacob's remarks are quoted by Dionysius bar Salibi (d. 1171) in the course of his lengthy discussion of the Gospel narratives; interestingly, he gives a manuscript variant for a couple of the names: «Jacob of Edessa says: (some) narratives say that Mary was the daughter of Ioiakin, from the tribe of Judah. He was the son of Estir - in (another) manuscript, Panther - and Estir was the brother of Melki, the son of Yani - in (another) manuscript, the one who was from Niri - who is descended in the genealogy from Nathan; and through (his) wife he (sc. Joseph) was from the tribe of Levi, and he was living in Galilee, in the place where the town of Tiberias was built». ${ }^{8}$ Since Jacob's main concern in his letter was to demonstrate Mary's Davidic descent, the link between Mary and the tribe of Levi, found in the narratives «by certain zealous people» receives no comment, and there is nothing in the text to suggest that this was seen as the source of Christ's priesthood.

Although Joachim and Anna as the parents of Mary came to dominate the later tradition in both East and West, they were not the only names to be accorded to them. Indeed, immediately preceding his quotation from Jacob of Edessa, Dionysius bar Salibi says. «It is asked, Who were Mary's parents? Her father is called Ioaqim, Ioakin, Ionakir," Sadoq, Iozedeq; and again his mother is called (both) Hanna and Dina».

Slightly earlier in his discussion Dionysius bar Salibi does indeed provide Mary's parentage through Sadoq and Dina, and the verbal parallels (indicated by italics below) with our text in Sinai Syr. 16 strongly suggest that both texts go back to a common souce. After discussing Julius Africanus' explanation of Joseph's genealogy, he continues:

${ }^{7}$ British Library, Add. 12172, f. 89r. The passage is printed in Wright's Catalogue, p. 597, and the full letter was published by F. NAU, Lettre de Jacques d'Edesse sur la généalogie de la Sainte Vierge // ROC 6 (1901) 512-531. The relevant text is on p. 519. The genealogy to which Jacob objects is in fact to be found in the Doctrina Jacobi Nuper Baptizati (CPG 7793; ed. V. DÉRoche in TM 11 (1991)); a Syriac translation of precisely this passage (I.42) is preserved in British Library Add. 17194, dated 885/6, published with French translation by F. NAU in $P O 8$ (1912) 721-722.

${ }^{8}$ Commentarii in Evangelia I.1 / Ed. I. SedlaceK, I.-B. Chaвот (CSCO 15-16) 50 (text), 38 (tr.).

${ }^{9}$ This is found in the Cave of Treasures (ed. A. Su-Min RI) XLIV.47 and in the Syriac Life of the Virgin edited by E. A. W. Budge, The History of the Blessed Virgin Mary and the History of the Likeness of Christ (London, 1899) 5 (this text seeks to harmonize a number of originally separate traditions; a similar harmonization is to be found in Solomon of Bosra, Book of the Bee, XXXIV). 
He did not attach the genealogy to Mary and say «N begot Mary, from whom Christ was born», since it was not the custom of the Hebrews for genealogies to be traced through women. For this reason he does not enumerate Mary's (ancestry), but Joseph's, so that he should not be seen to be confusing the ordering. We furthermore say that, through the mention of Joseph, it is known that the Virgin, along with him, descends from David, since there was intermarriage within each tribe. Even though a few women married outside their tribe, Joseph and Mary were both grandchildren of two brothers: a certain Eleazar begot two sons, Mathan and Jotham; Mathan begot Jacob, and Jacob begot Joseph, while Jotham begot Sadoq and Sadoq (begot) Mary. ${ }^{10}$ And the name of her mother was Dina, — and she is the sister of Elisabeth, whence the (angel's) words «Behold, your relative Elisabeth» (Lk 1:36). The matter was arranged by the divine Will so that the kingdom and priesthood, of David and of Levi, should receive fulfilment in Christ.

Basically the same information is to be found in an extract to be found in British Library, Add. 17168, f. 181v, which turns out to be an exact quotation of the opening of the text in Sinai Syr. 16:

Eleazar had two sons, one Mathan and the other Yotham. Joseph's lineage is from Mathan, and Mary's from Yotham. Eleazar's son Mathan begot Jacob, and Jacob begot Joseph, while Eleazar's son Yotham begot Zadoq, and Zadoq begot Mary by his wife Dina, who was the sister of Elisabeth, the wife of Zechariah. ${ }^{11}$

The second half of the text qoted by Dionysius (from «Eleazar begot...» to the end) is also found in the Commentary on the Gospel by the East Syriac scholar Isho' dad of Merv ${ }^{12}$ (flourished mid ninth century), with wording in the last sentence that corresponds closely with that of Dionysius, against that of Sinai Syr. 16. Since Dionysius is known to have used Isho'dad's commentaries, he may well be quoting directly from Isho`dad, and not from a common source; Isho`dad, however, speaks of «the priesthood of Aaron» (rather than that of Levi), and he adds at the end «from their shadows (i. e. types)».

Sadoq and Dina as the names of Mary's parents are also known from an East Syriac source attributed to Theodore of Mopsuestia. Amongst the prefatory material found in a number of East Syriac Gospel manuscripts is a text on the Gospel genealogies. This starts out by resolving, along the lines of Julius Africanus, the apparent disagreement between Matthew and Luke over

${ }^{10}$ The variation between Zadoq and Sadoq is also found for homonym in the Gospel genealogies (Mt 1:14, where the Old Syriac has Zadoq, while the Peshitta and Harklean have Sadoq.

${ }^{11}$ The Syriac text is printed in Wright, Catalogue... 800.

${ }^{12}$ The Commentaries of Isho`dad of Merv / Ed. M. L. Gibson (Horae Semiticae 5-6; 1911) 20-21 (text), 12-13 (tr.). 
the ancestors of Joseph; and to help the reader a diagram is also provided. The text reads: ${ }^{13}$

$$
\begin{aligned}
& \text { ת. }
\end{aligned}
$$

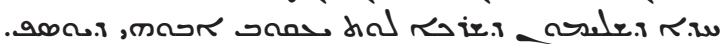

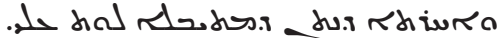

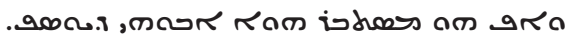

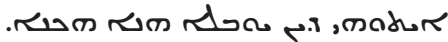

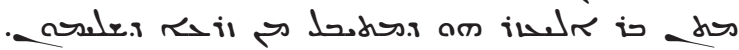

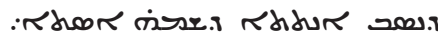

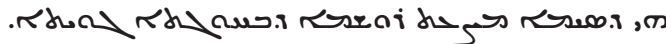

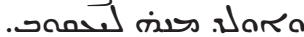

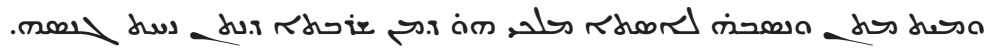

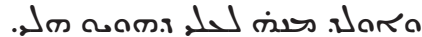

$$
\begin{aligned}
& \text { תiمhos }
\end{aligned}
$$

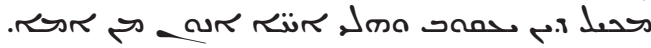

$$
\begin{aligned}
& \text { a } \\
& \text { חדו. }
\end{aligned}
$$

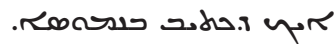

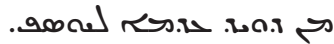

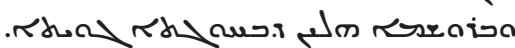

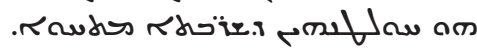

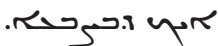

ס.

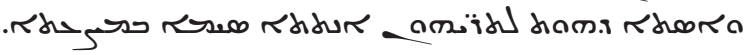

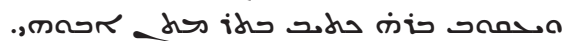

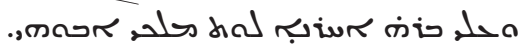

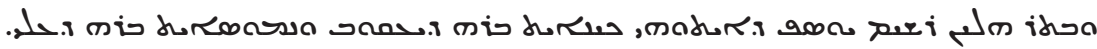

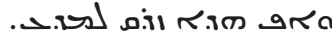

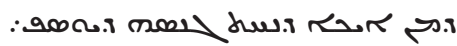
.

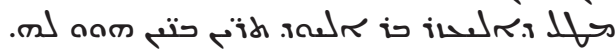

${ }^{13}$ I have used Harvard Syr. 4, dated AG 1511 (= AD 1199/1200), written in the Monastery of Rabban Sabrisho`, and British Library, Or. 2695, dated AG 1514 (= AD 1202/3) and AH 599 (= AD 1200/1) and written in the monastery of Mar Isho yahb and Mar Ya 'qob in Beth Nuhadra. (For these monasteries, see J-M. FIEY, Assyrie chrétienne (Beirut, 1965) I. 130-157, and II. 707-737). The text also features in several other East Syriac Gospel manuscripts of this period. 


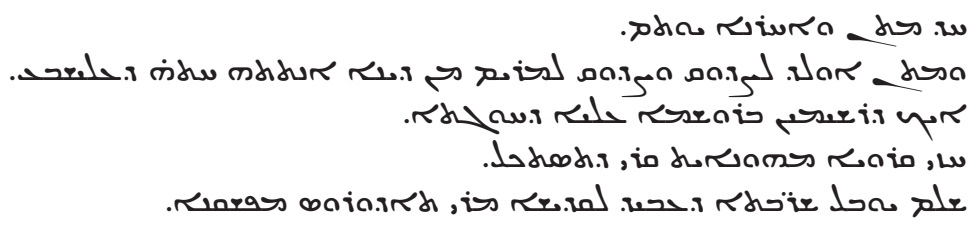

There are two lines, then, which descend from the blessed David, one on Solomon's side, which reaches to Jacob, the father of Joseph, and the other on Nathan's side, which descends to Eli, who was also considered to be the father of Joseph.

The line of descent is as follows: Mathan, son of Eleazar, descends from the seed of Solomon; he married a wife called Esta: she is to be found in the centre of the diagram, in the inner ring. By her he begot Jacob. Mathan (then) died and Melki married Esta. Now Melki's family was from the line of Nathan. By her Melki begot Eli, the same person as Heli: ${ }^{14}$ in the diagram he is called Heli. Thus Jacob and Heli were brothers by the same mother. Eli married, but died without children; his brother Jacob then married his widow in order to establish offspring from him, as it is written in the Law (Deut 25:5). By her he became father of Joseph, who was the natural son of Jacob, as is written in Matthew, but for legal purposes he was reckoned as the son of Heli, as Luke describes - so that there might be no room for fault-finders: whether they wanted to reckon the matter according to nature, or according to law, Christ was still the son of David. Thus you should know that the line of descent of the two families is indicated in the outer ring (of the diagram), running from David to Joseph. By means of the indications in the inner ring, the fusion of the two families is shown, as though (indicated) by a finger. Mathan, son of Eleazar, is listed with his family, and Melki with his, while Esta, who was wife to both, is placed in the middle. Jacob, her son, is inscribed following Mathan his father; following these is marked Joseph, the natural son of Jacob and the legal son of Eli.

Thus far, the text is based on Julius Africanus' explanation in his Letter to Aristides. By way of conclusion, however, a paragraph concerning the genealogy of Mary is added:

One should also know that the source from which Joseph's family descends is the same as that from which Mary's does too, for Eleazar, son of Eliud (Mt 1:15), had two sons, the one Mathan, and the other Yotham. Mathan begot Jacob, and Jacob (begot) Joseph; likewise Yotham begot Sadok, and Sadok (begot) Mary by his wife Dina, who was the sister of Elisabeth, as is indicated in the outer ring (of the diagram).

14 'Eli is (surprisingly) the Harklean form, and Heli that of the Sinaiticus and Peshitta. 
The genealogy constructed by the holy Mar Theodore the Interpreter is ended.

It is at once obvious that this final paragraph comes from the same source as that from which the extract in Sinai Syr. 16 derives.

In all likelihood Sinai Syr. 16 is the earliest witness to this variant tradition, that the names of Mary's parents were not Anna and Joachim, but Dina and Z/Sadoq. ${ }^{15}$ The precise date, however, of the manuscript has been much disputed, thanks to the extremely conservative nature of the estrangelo hand employed. ${ }^{16}$ According to Nestle, Sachau was of the opinion that it could belong to the late sixth century, and Draguet (p. 33*) likewise considered a sixth-century date likely. By contrast both Lewis, in her Catalogue, and Harris (p. 4) preferred the seventh century, while Mingana, on the basis of Mingana Syr. 641 (which comes from Sinai Syr. 16), opted for «about AD 850». Although Mingana's allocation of dates is often very unsatisfactory, in this case there is good reason for thinking that he was at least right to exclude a sixth- or seventh-century date: as Nicole Zeegers-Vander Vorst correctly observed, ${ }^{17}$ the presence in the manuscript of some extracts taken from Jacob of Edessa, who died in 708, means that the manuscript must accordingly be dated to at least the eighth century. A further pointer to this sort of dating is provided by a scribal note on $\mathrm{f} .177 \mathrm{v}$ which is written in serto script: ${ }^{18}$ apart from Harvard Syr. 176 whose dating is uncertain (see НАтсн, Album... Pl. XCV, and M. H. Goshen-Gottstein, Syriac Manuscripts in the Harvard College Library. A Catalogue (Missoula, 1979) 110-111), at present the earliest known dated manuscript in serto script is British Library Add. 14548, of AD 790 (HATch, Album... Pl. XCVI). Thus, in all likelihood, Sinai Syr. 16 should be dated to the eighth or early ninth century.

${ }^{15}$ The tradition is alluded to in a certain number of considerably later writers, but these are not of concern here.

${ }^{16}$ Illustrations of it can be found in HARris, The Apology of Aristides, Frontispiece, and in R. Draguet, Fragments de l'Ambrosienne de Milan à restituer aux mss. syriaques Sinai 46 et 16, in Biblical and Patristic Studies in Memory of Robert Pierce Casey / Ed. J. N. Birdsall, R. W. Thomson (Freiburg, 1963) Plate V.

${ }^{17}$ Une gnomologie d'auteurs grecs en traduction syriaque // Symposium Syriacum 1976 (OCA 205; 1978) 166, n. 13.

${ }^{18}$ The scribe identifies himself as Mari son of 'tnws, from Edessa (this, apart from the name Mari, was noted by Bundy, Mus 96 (1983) 98, where he suggested that the father's name is a miswriting of Athanasius). Mari writes in a fully developed serto script, as opposed to the cursive hands of scribal notes in British Library Add. 14452 (of AD 509), Add. 14530 (of AD 535) and Add. 14558 (of AD 557); on which see F. BRiquel-Chatonnet, De l'écriture édéssienne à l'estrangela et au serto // Semitica 50 (2000) 81-90; also J. F. Healey, The early history of the Syriac script: a reassessment // Journal of Semitic Studies 45 (2000) 55-67. 
One further point requires mention: is Sinai Syr. 16 of Melkite or of Syrian Orthodox origin? Links between Sinai and the Melkite community in Edessa can be seen from a number of dated Syriac manuscripts, the earliest being British Library Or. 8606, dated $723 ;^{19}$ the presence in Sinai Syr. 16, however, of quotations from Jacob of Edessa suggests that this particular manuscript may well instead be of Syrian Orthodox origin. In either case, it is witness to interaction between the two communities at some stage or other.

Whatever the date of Sinai Syr. 16, it seems likely that the tradition it preserves concerning Mary's ancestry and Christ's levitical priesthood has much earlier roots: an interest in the latter in the latter half of the fourth century can clearly be seen in the Commentary on the Diatessaron, I.25-26, where the Syriac text provides objections to Mary's levitical ancestry, while the Armenian translation promotes it. ${ }^{20}$ The tradition of Christ's levitical priesthood - whether it be transmitted through Mary, or through John the Baptist, or through Simeon - is most likely to have a Judaeo-Christian origin, and this means that the wording preserved by Dionysius bar Salibi, that the kingdom of David and the priesthood of Levi were to «receive fulfilment» will represent this tradition more correctly than does the extract in Sinai Syr. 16, which speaks of the Old Testament kingship and priesthood as being rendered ineffective in Christ, reflecting a later supersessionist attitude.

Each of the two traditions for the names of Mary's parents - Joachim and Anna, and Zadoq and Dina ${ }^{21}$ — will have its roots in a different early Christian milieu: Joachim and Anna make their first appearance in the Protogospel of James, whose various misconceptions about Jewish traditions make a gentile Christian origin likely; while Zadoq and Dina provide a counterpart that very probably originates in Judaeo-Christian circles. Syriac literature provides evidence for other such pairs, notably in the legends of the finding of the Cross, with Constantine's mother Helena as the heroine in the mainstream tradition, but Claudius' wife Protonike in the tradition preserved in the Teaching of Addai. Our short text in Sinai Syr. 16 can thus be seen to provide another example of an intriguing phenomenon to which Michel van Esbroeck has drawn attention on a number of different occasions.

${ }^{19}$ For details, see S. BRock, Syriac on Sinai: the main connections // Eukosmia. Studi miscellanei per il 75 di Vincenzo Poggi S. J. / Ed. V. Ruggieri, L. Pieralli (Soveria Mannelli, 2003) 103-117.

${ }^{20}$ For a discussion of the problems raised by this contradiction, see TAYLOR, The priesthood of Christ... and LANGe, The descent of Mary... The position taken in the Syriac text has some resemblance to that of Eusebius, in his Questions and Answers on the Gospels (BEYER, Die evangelischen Fragen... 54-55).

${ }^{21}$ Whereas Anna/Hanna gets her name from Samuel's mother, Dina gets hers from Jacob's daughter. 


\section{APPENDIX 1 \\ The genealogical schemata given for Mary}

(1) Sinai Sin. 16.

Mary is said to descend on her father's side from the tribe of Judah, and on her mother's from the tribe of Levi.

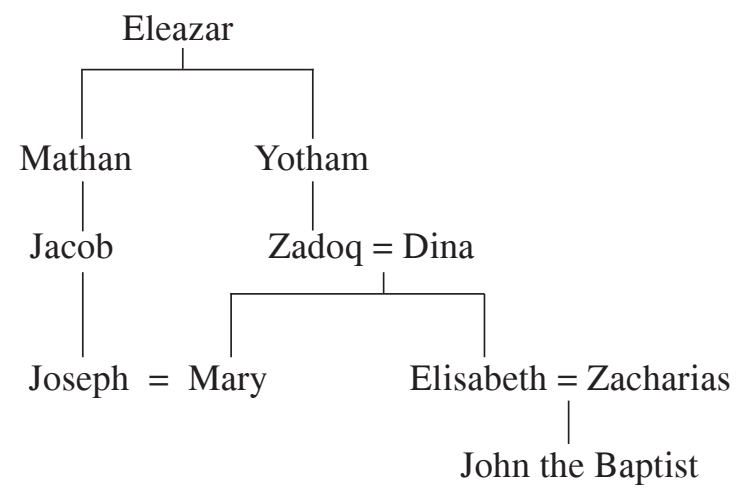

(2) Mary's relationship to Joseph, as added to Julius Africanus' explanation of Joseph's genealogy (Apocryphal books apud Jacob of Edessa).

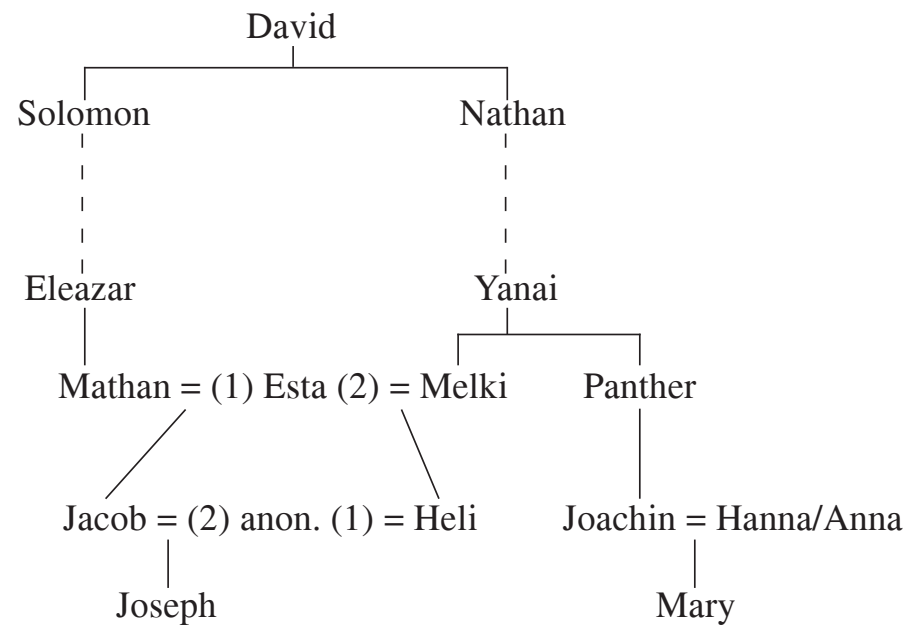

(3) Syriac Life of Mary (ed. Budge).

In contrast to Julius Africanus' schema, where Jacob is Joseph's natural father and Eli/Heli his legal father, the reverse is the case here. Dina is said to have been called Hanna from the time that she gave birth to Mary. 
Solomon

Nathan

Eleazar

Mathan

Matath

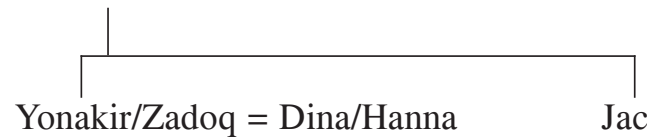

Jacob $=(1)$ Esta (2) $=$ Heli

Mary

Joseph

(4) Cave of Treasures XLIV.45-46.

(There is considerable variation in the spelling of some of the names).

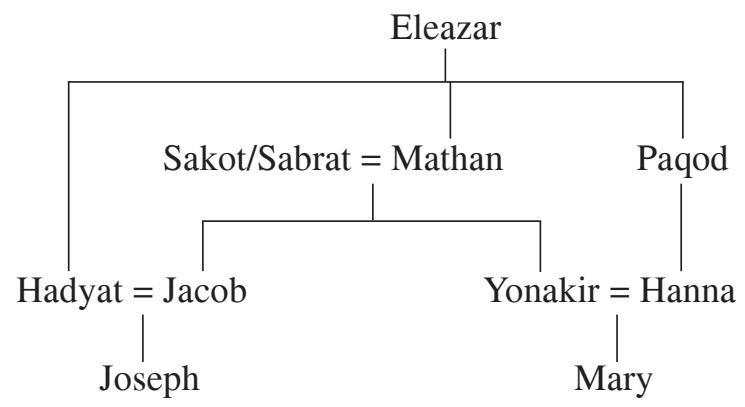

(5) Epiphanius the monk, Life of Mary, and other Greek texts:

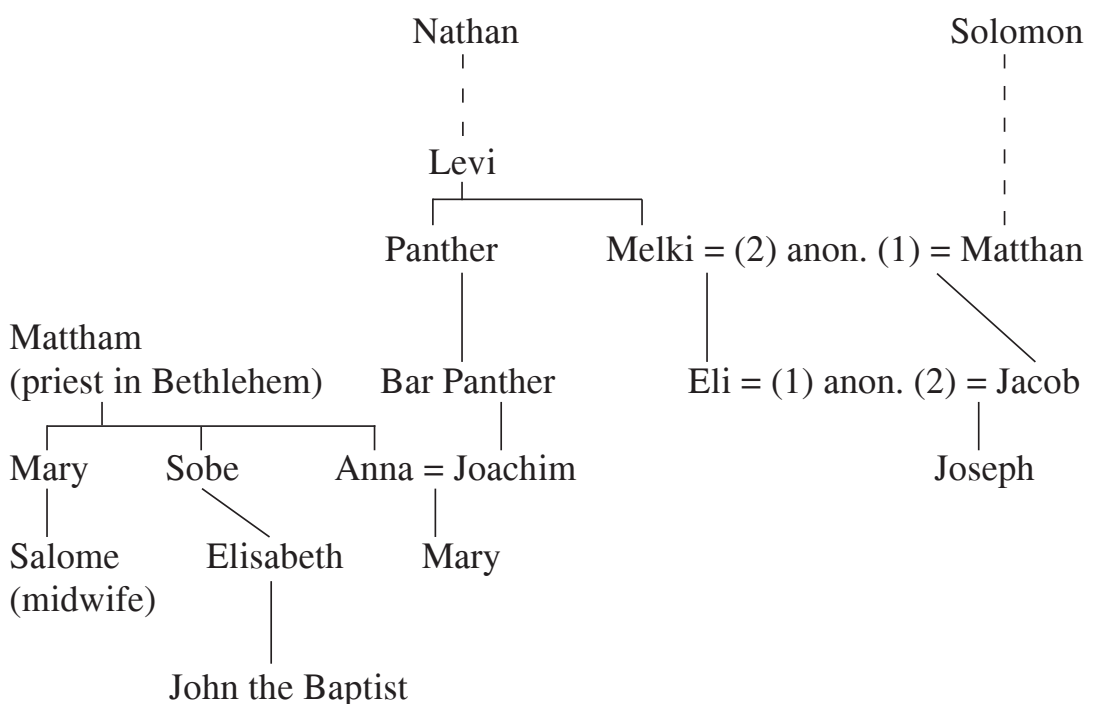




\section{APPENDIX 2 The contents of Sin. Syr. 16}

The following description of the contents is based on the present foliation (which probably goes back to the time of the microfilming of the manuscripts by the Library of Congress in 1950); it should be noted that the folio numbers given by J. Rendel Harris, The Apology of Aristides (Cambridge, 1891) 3-6, and by A. S. Lewis, Catalogue of the Syriac Manuscripts in the Convent of Saint Catherine on Mount Sinai (Studia Sinaitica 1, 1894) 18-38, in their descriptions of the manuscript will not correspond with those given below, since they were working before the removal of the first quire (folio 1 today represents the first folio of the second quire).

ff. 1-27r: Palladius, Lausiac History. R. Draguet's manuscript H in his Formes syriaques de la matière de l'Histoire Lausiaque (CSCO SS 169-170, 173-174; 1978). The missing first quire of Sinai syr. 16 is to be found in Milan A296 Inf, ff. 174-179 + Mingana syr. 641 + Milan A296 Inf. f.180 (see DraGUET, Les formes syriaques de la matière de l'Histoire Lausiaque (CSCO, Scr. Syri 169; 1978) 33*$34 *)$.

ff. 27r-56r: Nilus, On Monastic Life. P. BetTiolo's manuscript B in his Gli scritti siriaci di Nilo Solitario (Louvain, 1983) 46-151.

ff. 56r-68r: Apology of Aristides. Edited from this manuscript by J. RendeL HarRIS, The Apology of Aristides (Cambridge, 1891) (Texts and Studies I.1). Reedited in B. Pouderon, M-J. Pierre, B. Outtier, M. Guiorgadzé, Aristide, Apologie (Sources chrétiennes 470; 2003).

ff. 68r-75r: Plutarch. Edited from this manuscript by E. NestLE, A Tract of Plutarch on the advantage to be derive from one's enemies (Studia Sinaitica 4; 1904).

ff. 75r-84v: Plutarch, Peri askeseos. This is the same text as that edited from British Library Add. 17209 by P. DE LAGARDE, Analecta Syriaca (Leipzig, 1858; repr. Osnabrück, 1967) 177-186. The beginning, missing in Add.17209 (and so also in de Lagarde's edition), is edited from Sinai Syr. 16 by W. Rohlfs, PseudoPlutarch, Peri Askeseos // Paul de Lagarde und die syrische Kirchengeschichte (Göttingen, 1968) 176-184.

ff. 84v-89r: Discourse of Pythagoras. This is the same text as that edited from Add. 14658 by de Lagarde, Analecta Syriaca... 195-201.

ff. 89r-95v: Plutarch, Peri aorgesias. This is the same text as that edited from Add.17209 by DE LAGARDE, Analecta Syriaca... 186-195.

ff. 95v-103r: Lucian, Peri tou me radios pisteuein diabole. This is the same text as that edited from Add. 17209 by E. SACHAU, Inedita Syriaca (Halle, 1870; repr. Hildesheim, 1968) 1-16.

ff. 103r-105r: Discourse by a philosopher on the soul. Printed by LewIS, Catalogue... 19-26. This text is elsewhere attributed either to Aristotle or to Gregory 
Thaumaturgus: see my Clavis Patrum Graecorum III, 7717 // JTS ns 32 (1981) 163-177.

ff. 105r-108v: Theano, Counsels. This is the same text as that edited from Add. 14658 by SACHAU, Inedita Syriaca... 70-75. German translation by U. PosSEKEL, Der Rat der Theano. Eine pythagoreische Spruchsammlung in syrischer Überlieferung // Mus 111 (1998) 7-36. (Sinai Syr. 16 provides the text for the passages that Sachau could not read; I hope to edit this on another occasion).

ff. 108v-109r: Plato, Definitions. This is the same text as that edited from Add. 14658 by Sachau, Inedita Syriaca... 66-67.

f. 109r-v: Plato, Instruction to a pupil. This is the same text as that edited from Add. 14658 by SACHAU, Inedita Syriaca... 67-69.

f. 109v: Short definitions, on faith etc. This is the same text as that edited from Add. 14658 by SACHaU, Inedita Syriaca... 69.

ff. 109v-114v: Sayings of the Philosophers. These are edited by Lewis, Catalogue... 26-38. On these sayings, see N. ZeEgERs-van DER Voorst // Symposium Syriacum 1976 (OCA 205; 1978) 163-177.

ff. 114v-177v: John the Solitary, Commentary on Ecclesiastes. Edited from this manuscript by W. Strothmann, Der Kohelet-Kommentar des Johannes von Apamea (GOFS 30; 1988).

ff. 177v-184v: John Chrysostom, On the Canaanite Woman (CPG 4529). Sinai Syr. 16 is D. Bundy's manuscript $S$ in his edition, in Mus 96 (1983) 97-132

ff. 184v-200r: John (yhwnys) Chrysostom, excerpts from his Homilies on Matthew (CPG 4424).

$184 \mathrm{v}$ «On the young man from whom Legion departed, and on humility».

186r «From Discourse 28».

$191 \mathrm{r} \ll$ From the Discourse on the person who has sinned, that he should not despair because he has fallen».

$195 \mathrm{r}$ «From the Discourse on "If your brother has wronged you, rebuke him between yourselves».

f. 200r: «The Fathers of the circle of Gregorios», On the genealogy of the Virgin (the text discussed above).

f. 200v: (the title is too faded to read).

f. 201r: Jacob of Edessa, On Paradise. (This is not from his work on the Hexaemeron).

f. 202r: Ephrem, On Paradise. (This short extract is in 7:7 metre).

f. 202v: Mar John (yhwnys). (On Satan counselling despair to the sinner).

f. 202v: Mar Jacob. (On «every knee shall bow» before the Bema at the Last Judgement).

f. 203r: Questions posed by Yohannan to Jacob (probably, of Edessa). (On Adam's skull).

f. 203v: Mar John (yhwnys), to Gregory the Anagnostes (Reader). (On «Even though heaven and earth will pass away, my words will not pass away»). No addressee with this name is known in John Chrysostom's correspondence. 
f. 204 does not belong to the original manuscript. Blank, apart from a note of ownership by the monastery on Sinai in a hand of c. $10^{\text {th }} / 11^{\text {th }}$ century.

\section{Codicological details}

Material: parchment.

Script: neat Estrangelo, one column ff. 1-56r; 2 columns ff.56v-end (the change over - probably involving different scribes — occurs mid text). For published photographs and discussion of the date, see above.

Measurements: $16.5 \times 24.8 \mathrm{cms}$; area of writing $10.7 \times 16.5(\mathrm{ff} .1-56 \mathrm{r}), 11.7 \times$ 17.5 (ff.56v-end).

Prickings: these take the form : : (for the single columns) and : : : : (for the double columns).

Lines per page: c. 27 (ff. 1-56r); c. 34 (ff. 56v-end).

Quire numbering: quires (of 10ff.) are numbered on the inner lower margins of the recto of the first, and verso of the last, folio of each quire for quires 2-5 (= ff. $1 \mathrm{r}-40 \mathrm{v})$, after which the numbers are only given on the recto of the first folio of each quire (except quire 7; between f.51 and the end the quire numbering indicates that a few folios must be missing here and there).

Page headings: these are found with only partial regularity on the verso of the fifth and tenth folio of each quire.

Incorporated into the binding at the front and back are two fragments in an estrangelo hand of the sixth century; these can be identified as being from Aphrahat, Demonstration XXIII.59-60 (at the beginning, corresponding to Patrologia Syriaca II, cols. 124-125; at the end, to col. 120).

\section{SUMMARY}

The Gospels of Matthew and Luke only provide a genealogy for Joseph. Speculation concerning Mary's ancestry is first found in the Protogospel of James. In due course other writers offered a variety of different genealogies, one of which (to be found in Sinai Syr. 16) is published here. According to this genealogy Mary was the daughter of Zadoq and Dina (rather than the familiar Joachim and Anna). The other witnesses to this variant tradition, and the motivation behind it, are also discussed. In an appendix a full description of the contents of Sinai Syr. 16 is given (among the several important texts is the Apology of Aristides) 